\title{
sciendo
}

DOI: 10.1515/aon-2019-0006

\section{MODELING THE LOCATION AND ROUTING PROBLEM FOR THE DISTRIBUTION OF LIQUEFIED NATURAL GAS}

\author{
EWELINA CHŁOPIŃSKA \\ Maritime University of Szczecin, Poland \\ 1-2 Wały Chrobrego St., 70-500 Szczecin, Poland, \\ e.chlopinska@am.szczecin.pl, \\ MACIEJ GUCMA \\ Maritime University of Szczecin, Poland \\ 1-2 Wały Chrobrego St., 70-500 Szczecin, Poland, \\ m.gucma@am.szczecin.pl
}

\section{INDRUCTION}

At the time of the ongoing development of technology, first and foremost in industry and automation, attempts are made to devise increasingly innovative, environment-friendly technical solutions. The improvement of manufacturing processes allowed the use of natural gas as an energy carrier, currently the most valuable raw material. LNG is created from gaseous state in the process of liquefaction. This change in the state of matter allows the volume of gas to be reduced 600 times so that it can be profitably transported over long distances. In global trade, a quarter of natural gas is transported in a liquefied state. The process of gas liquefaction entails very thorough purification of the gas, separating compounds harmful to health and the natural environment. LNG is a very clean and safe fuel, characterized by, inter alia, complete elimination of moisture.

LNG use in sea shipping is reflected in the developments of the global maritime fleet. The projections of the growth of LNG-powered fleet are very optimistic [3]. Due to the numerous regulatory instruments to protect the environment, areas of strict sulphur emissions control (SECA) may in the future become areas crisscrossed mainly by ships using LNG as their primary fuel. There will be significant increase in the demand for natural gas [6], [8], [9]. This raw material can be effectively used to meet the energy needs of areas located away from the gas infrastructure, which will result in dynamic development of low sulphur fuel trade.

\section{LNG DEMAND}

Global maritime trade is presently facing low freight rates and high fuel costs. The use of liquefied natural gas for the propulsion of ocean-going vessels was one of the steps in finding ways to satisfy the requirements of the 'Sulphur Directive'. For shipowners, LNG is an ideal solution to the problem of excessive sulphur content in marine fuels and to the needs of modern society. The developing global LNG market enables the continuous expansion of many accompanying industrial sectors that have a measurable share in each link of the supply chain. This phenomenon is also affected by increasing use of this fuel in various areas of the global economy. Gas distribution plays a major role, whose importance is constantly increasing due to LNG introduction into SECA areas. 
It is assumed that 15 million tonnes of LNG can be used by the maritime industry within five to seven years, and this level will be growing to reach 30 million tonnes in 2030 [13]. The estimated number of sea-going vessels powered by LNG will increase from 100 in 2018 to 1000 in 2020 [14].

The demand for low sulphur bunker fuel is observed to grow. The projections for sea-going vessel bunkering are varied, ranging from $0.1 \%$ to $3 \%$ of global LNG production. As presented in the chart below (Fig. 1), showing average values of global LNG production in 2012, the bunker gas fuel demand was estimated at about 100,000 tonnes. In 2025, there will be an increasing trend, reaching a level of between 2.5 and 15 million tonnes, (the averaged value of 7.5 million tonnes [7]).

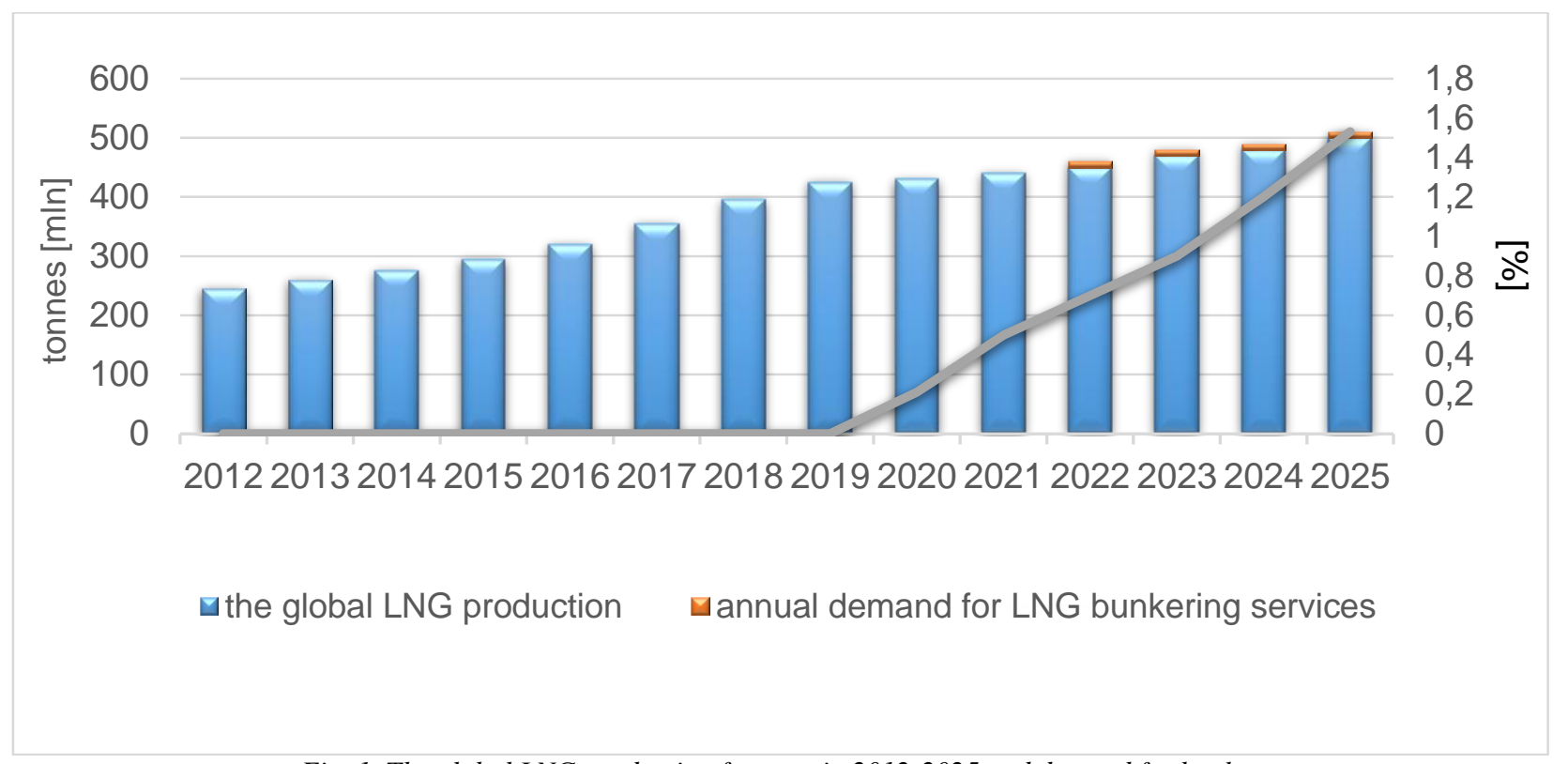

Fig. 1. The global LNG production forecast in 2012-2025 and demand for bunker fuel for ships - mean value.

Source: own elaboration based on [3]

The process of growing LNG use is related to the large number of long-term investment projects that will bring to investors continuous and dynamic development of the maritime industry. Figure 2 below presents the rate of introducing LNG at sea.

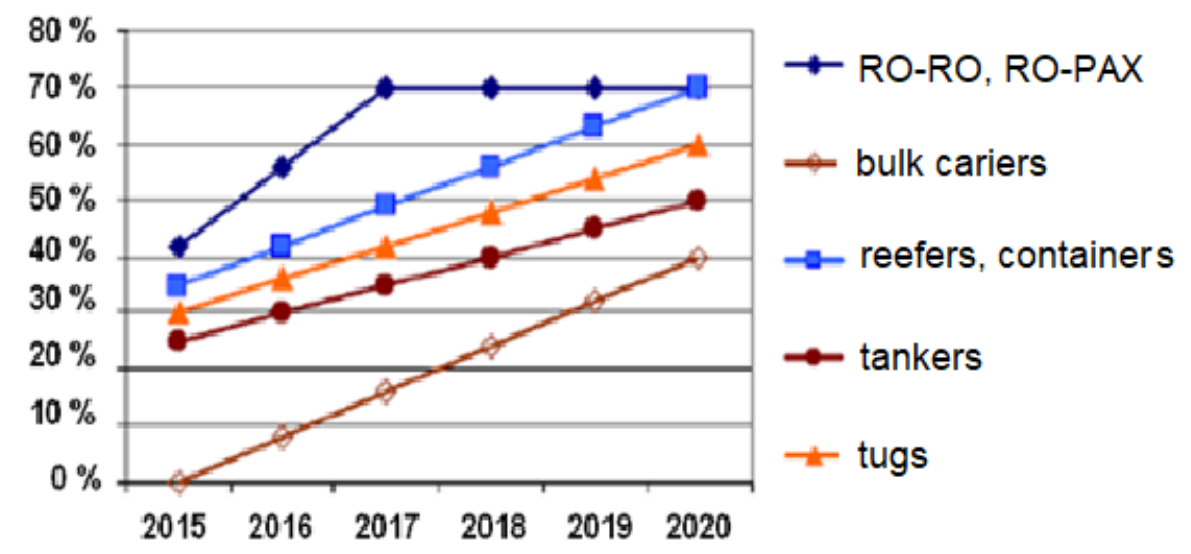

Fig. 2. The rate of $L N G$ use growth. Source:[3]

According to the data of the DNV GL classification society, currently 77 sea-going vessels are run on LNG fuel worldwide, while 85 LNG-powered vessels have been ordered. By 2020, LNG-powered fleet will consist of 400 to 600 vessels. Vessels providing their services in the Baltic Sea area are up to 40 years old. The 25\% 
replacement of the fleet will take up to 10 years. If the propulsion fuel is to be changed, the shipowners, apart from choosing newbuildings with LNG powered engines, may consider converting the existing engine installations. $10 \%$ to $15 \%$ of the newbuildings put in operation by 2020 will be powered by liquefied natural gas (Fig. 3. The global LNG-powered vessels forecast by 2025.), i.e. approximately 1000 vessels. In the next six years, more than one ship out of ten newbuildings will be equipped with an LNG-fuelled engine. [3]

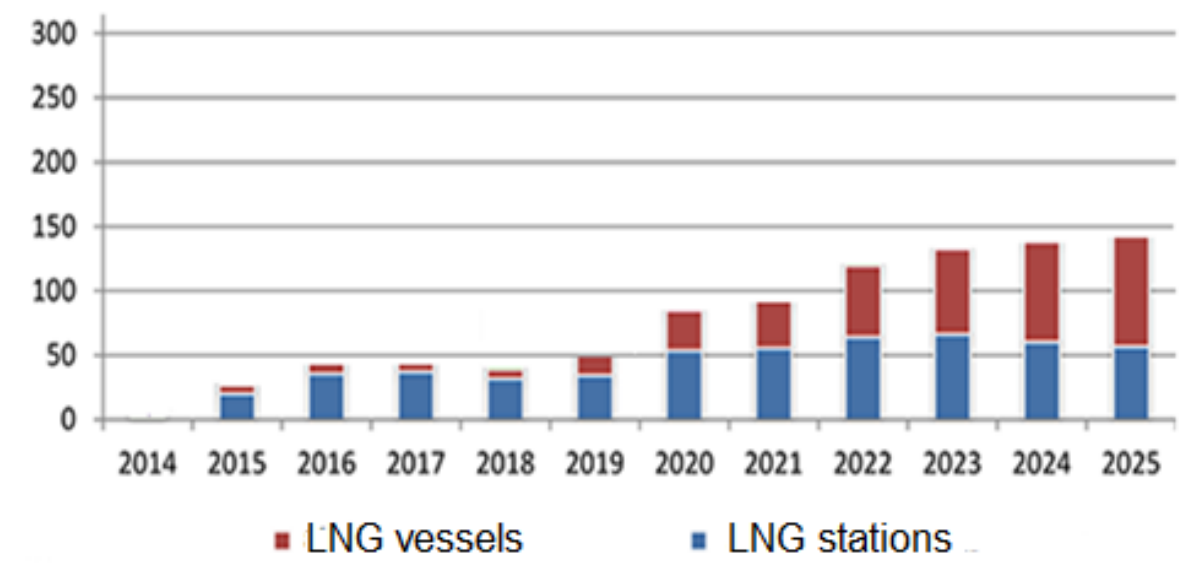

Fig. 3. The global LNG-powered vessels forecast by 2025. Source: own elaboration based on [3]

According to the statistics of the European Union Statistics Office, based in Luxembourg, in the second quarters of the years 2014-2016 the mean price of natural gas was $41.3 € / \mathrm{MWh}$ for households. For the industry, the price was $70.7 € / \mathrm{MWh}$ (2016 gas got cheaper [5]). In the examined period, the industry witnessed an average decrease in the prices by 7\%, while for the households until 2008 increased prices were noted, then, in the years 2014 to 2016 gas got cheaper [5].

In the years to come the factor critical for the use of low sulphur fuels will be the ratio of LNG and MGO prices. This also applies to the prices of marine fuels in the years 2014 to 2025 . Liquid fuels are particularly susceptible to changes, the effect of considerable fluctuations of crude oil prices. Favourable economic conditions for the supply of LNG to Poland will, inter alia, result from LNG technology cost that tends to decrease on a continuous basis. National energy investment projects will have a major impact on the price. By diversifying the supply sources through the LNG Terminal in Świnoujście, Poland will become less dependent on gas supply from Russia and will be competitive in the gas market. The LNG price at the Polish Power Exchange in Warsaw is $69 \mathrm{zt} / \mathrm{MWh}$. The average cost of US delivered LNG is at present $113 \mathrm{z} / \mathrm{MWh}$. The price includes the margin of the US exporter - Cheniere Energy and the costs associated with the liquefaction and regasification in Poland [5].

\section{LNG DISTRIBUTION AND GENETIC ALGORITHMS.}

Three ports are efficiently operated in the Baltic Sea area in terms of LNG bunkering of vessels - Stockholm, Klaipeda and Turku. The adaptation to new regulations affecting sea-going vessels will lead to the emergence of systems and installations adapted for ship bunkering in areas under strict sulphur emission control. The availability of LNG for sea-going vessels in the area of land infrastructure (along the whole Baltic Sea shoreline) and in the high seas will solve the problems of the lack of the bunkering availability.

Genetic algorithms are used to solve the classic problem, i.e. combination of two interdependent quantities: routing and the availability of distribution facilities. The solution to the routing problem of LNG-powered vessels will enable the formulation of tasks, being the modification of the original task. The essential advantage of genetic algorithms is that there is no need to make changes (except for stating the objective function), in the general originally written algorithm. The appropriately defined objective function can be solved for problems referring to: 
- time of LNG storage;

- length of the route;

- determination of initial and final points;

- additional LNG bunker ships and auxiliary LNG storage facilities;

- determination of the frequency of bunkering th LNG-powered vessels;

- time windows;

- possibility of handling one LNG-powered ship by a few LNG bunker vessels;

- determination of the order of bunkering LNG-powered vessels;

- the costs.

There are many methods of solving the problem of vehicle routing. The basic division is into accurate and approximate (heuristic) methods. Taking into account the basic characteristics of the accurate methods (work intensity and long time of searching for an optimal solution), the capability of these methods manisfests itself when tasks with a low number of points are considered. In the case of heuristic methods, the solution to a given problem is close to an optimal one (and acceptable) from the viewpoint of the time of its achievement. The solving time is much shorter than that for the accurate methods. However, it should be noted that the approximate methods do not provide the certainty of getting an optimal solution. Heuristic methods can be classified as follows [1], [2]:

a) constructive methods - where at the same time the recipients are assigned to the specific points and the sequence of visiting them by given vehicle is determined, e.g.:

a. Clark-Wright savings algorithm,

b. H. Paessens method,

c. R.H Mole and S.R. Jamison algorithm;

b) decomposition methods - separate determination of the delivery area (adjusting the points to the relevant vessels) and the sequence of visiting these points, e.g.:

a. sweep algorithm of B.E. Gillett and L.R. Miller,

b. BF-WOT A. Całczyński's algorithm;

c) growth methods (local optimization methods) - strategy of seeking an optimal solution by replacing the given solution with a new better one.

\section{EVOLUTION PROCESS OF THE VEHICLE ROUTING}

The concept of genetic algorithms is to imitate processes observed in nature in the artificial environment (selection of individuals, evolution of species, reproductive mechanisms, inheritance of the characteristics) [10], [11], [12]. The theory of genetic algorithm, belonging to the group of non-deterministic methods indicating optimal solutions, is based on the theory of evolution. The idea was developed by John Henry Holland in the 1960s and 1970s [4]. The characteristic feature of the algorithms is modelling based on the theory of natural selection and evolution - inspired by biological analogies. Therefore, genetic algorithm is the 
term defining optimization methods derived from biological evolution processes. The optimization process is the search of an area of possible solutions in order to find the best outcome. The area of potential results in real use is extremely large and the verification of all solutions for getting the best outcome is impossible. Therefore, it is justified to use probabilistic techniques using the random choice as the tool of the search process. In comparison to the environment, the algorithm enables the acquisition of increasingly better solutions. The fact that genetic algorithms can solve optimization problems results from the biological process of the evolution, where only the fittest individuals are able to survive, and create new, correct solutions. In the natural environment, individuals that will not be able to maintain themselves will become extinct. The strongest individuals, in contrast, will transmit the good genes to the next generations by reproduction. In the long run, strong individuals carrying genetically correct combination take the lead in the population. Throughout the process of evolution taking place in nature an accidental change in genes may occur. Modifications that bring extra benefits in the struggle for survival lead to transformation of the created individuals. Incorrect modification is excluded by nature itself.

The genetic algorithm starts from the preliminary phase - initialization. The first stage consists in the formation of a population of possible solutions (individuals) represented by chromosomes having genetic information about individuals. Basic parameters of the algorithm are established: length of chromosome, population size, factor determining the probability of selecting chromosomes (the principle of elitism), factor determining the probability of a crossover, a factor determining the probability of mutation.

In each evolutionary step, chromosomes are decoded and analysed according to the assumed criteria of fitness quality - the objective function. The weakest, least fit individuals are eliminated through a selection. On the other hand, highly fit individuals are subject to the process of mutation and recombination using the crossover operator. The evolutionary process resulting from the actions of crossover and mutation operator creates solutions from which the next generation population is built. The condition for termination of the selection of the best-fit chromosome of the evolution process is either reaching the defined number of generations or a satisfactory fitness level.

According to the principle of elitism, one of the best equipped chromosomes is copied to the new population. To ensure that the each subsequent population fits better, it is assumed that chromosomes from the previous population with the highest values of the fitness function have the greatest impact on a new population. The greatest probability of evolution comprises solutions with the highest degree of fitness, defined by the value of the fitness function (objective function of the optimization task). The genetic algorithm is an convenient tool that is widely used in solving complex decision making processes, e.g. routing of bunker ships using LNG propulsion and for the location of LNG storage facilities.

The particular feature of genetic algorithms, the most important for solving the given task of LNG distribution, is that the objective function is easily transformed to find a set of minor acceptable solutions in the examined population. The ability to search synchronically various spaces enables solving complex problems with several objective functions. 


\section{SUMMARY}

Programming methods, such as dynamic heuristic search or search and limit techniques are used for solving the problems of routing. Many of the problems to be solved require huge computing effort, some of them are NP-hard. Other optimization algorithms that may be used for solving vehicle routing problems are methods based on genetic algorithms, neural networks and ant algorithms.

The problem of LNG distribution system is closely related to the problem of route planning. These problems are characterised by a simple definition of the problem, unlike finding the solution. Finding the optimal outcome for a great number of points is a hard and work-consuming task. Genetic algorithms are an alternative for the methods most often used so far.

\section{REFERENCES}

[1] Biały R., Janusz P., Łoś M., i Szurlej A., „Analiza kosztów importu gazu ziemnego do Polski i ich wplyw na strukture dostaw.", Zeszyty Naukowe Instytutu Gospodarki Surowcami Mineralnymi i Energia PAN, nr 87, ss. 83-98, 2014.

[2] „BP Statistical Review of World Energy”, BP, 2017.

[3] Data of DNV GL, 2018.

[4] European Maritime Safety Agency., „The 0.1\% sulphur in fuel requirement as from 1 January 2015 in SECAs - An assessment of available impact studies and alternative means of compliance.”, European Maritime Safety Agency., Technical report, 2010.

[5] European Statistical Office, „Market Forecast Report”, Belgia, 2017.

[6] Grzelak S., „Liquefied Natural Gas - a Strategic Fuel. Poland's Security with Regard to Gas Fuels.”, Kontrola Państwowa, t. 60, nr 6 (365), ss. 133-145, 2015.

[7] Herdzik J., „Wstępna analiza opłacalności tworzenia sieci bunkrowania skroplonego gazu naturalnego LNG w portach Morza Battyckiego.”, Logistyka., nr 3, ss. 2359-2366, 2014.

[8] IGU, ,World LNG Report.”, Norwegia, 2016 Edition., 2016.

[9] Kalski M., Nagy S., Rychlicki S., Siemek J., i Szulej A., „Gaz ziemny w Polsce - wydobycie, zużycie i import do roku 2030.”, Górnictwo i ekologia., t. 5, nr 3, ss. 27-40, 2010.

[10] Kwaśnicka H., „Sztuczna inteligencja. Algorytmy ewolucyjne - przykłady zastosowań.”, Zeszyt Naukowy Sztuczna Inteligencja., nr 1, 2002.

[11] Michalewicz Z., Algorytmy genetyczne + struktury danych = programy ewolucyjne. Warszawa: Wydawnictwo Naukowo-Techniczne, 1999.

[12] Peňa-Reyes C. A. i Sipper M., „Evolutionary computation in medicine: an overview. ”, Artif. Itell. Med., nr 19, ss. 1-23, 2000.

[13] Prognoza floty morskiej, 2017. On-line: www.cttm.am.szczecin.pl.

[14] Prognoza globalnego zapotrzebowania na LNG do 2030 roku.”, 2017. On-line: www.promy24.com 